Spring 2015

\title{
On Flogging the Dead Horse, Again: Historicity, Genealogy, and Objectivity in Richard Waterman's Approach to Music
}

Michael lyanaga

William \& Mary

Follow this and additional works at: https://scholarworks.wm.edu/aspubs

Part of the Ethnomusicology Commons, and the Latin American Languages and Societies Commons

\section{Recommended Citation}

lyanaga, Michael, On Flogging the Dead Horse, Again: Historicity, Genealogy, and Objectivity in Richard Waterman's Approach to Music (2015). Ethnomusicology, 59(2), 173-201.

https://doi.org/10.5406/ethnomusicology.59.2.0173

This Article is brought to you for free and open access by the Arts and Sciences at W\&M ScholarWorks. It has been accepted for inclusion in Arts \& Sciences Articles by an authorized administrator of W\&M ScholarWorks. For more information, please contact scholarworks@wm.edu. 


\section{the society for \\ UNIVERSITY OF ethnomusicology ILLINOIS PRESS}

On Flogging the Dead Horse, Again: Historicity, Genealogy, and Objectivity in Richard Waterman's Approach to Music

Author(s): Michael Iyanaga

Source: Ethnomusicology, Vol. 59, No. 2 (Spring/Summer 2015), pp. 173-201

Published by: University of Illinois Press on behalf of Society for Ethnomusicology

Stable URL: https://www.jstor.org/stable/10.5406/ethnomusicology.59.2.0173

\section{REFERENCES}

Linked references avalable on JSTOR for this article: https://www.jstor.org/stable/10.5496/ethnomusicology.59.2.0173? seq=1\&cid=pdfreference\#references_tab_contents

You may need to $\log$ in to JSTOR to access the linked references.

JSTOR is a not-for-profit service that helps scholars, researchers, and students discover, use, and build upon a wide range of content in a trusted digital archive. We use information technology and tools to increase productivity and facilitate new forms of scholarship. For more information about JSTOR, please contact support@jstor.org.

Your use of the JSTOR archive indicates your acceptance of the Terms \& Conditions of Use, available at https://about.jstor.org/terms 


\title{
On Flogging the Dead Horse, Again: Historicity, Genealogy, and Objectivity in Richard Waterman's Approach to Music
}

\author{
Michael Iyanaga / The College of William and Mary
}

\begin{abstract}
In a critical appraisal and expansion of the historical methodology championed by ethnomusicologist and anthropologist Richard Waterman, this essay reconsiders the historicity of musical performance and demonstrates ways in which treating ethnography genealogically may serve as a means of doing what Thomas Solomon calls "postcolonial music history." This essay is broadly divided into three parts: a review of Waterman's work, a theoretical revamping and an abbreviated case study taken from my own research on Catholic patron saint rituals in Bahia, Brazil.
\end{abstract}

Resumo. Através da avaliação e ampliação críticas da metodologia histórica difundida pelo etnomusicólogo e antropólogo Richard Waterman, este trabalho reconsidera a historicidade da performance musical e busca demonstrar como o tratar genealógico da etnografia pode servir para a construção daquilo que Thomas Solomon chama de "história pós-colonial da música." O presente trabalho é divido em três partes: a apresentação da obra de Waterman, a reformulação teórica desta e um abreviado estudo de caso oriundo de minha pesquisa sobre os rituais realizados para os santos católicos padroeiros na Bahia (Brasil).

$\mathrm{I}$

n 1963 Richard Waterman published an article in Ethnomusicology entitled "On Flogging a Dead Horse: Lessons Learned from the Africanisms Controversy." It was a concise reflection on twenty years of arguing that African musical style survived in the New World by way of musical "Africanisms." According to Waterman, the article's "inelegant title" referred to his "initial feeling of distaste" in having to revisit the topic (R. Waterman 1963:83). The "horse" in the article's

(C) 2015 by the Society for Ethnomusicology 
title was a metaphor for the controversy over whether or not African history and social patterns remained in African-American New World cultures. Some scholars, including Waterman and his colleagues, believed African cultural forms continued to thrive in the Americas while others argued that African Americans had been stripped entirely of any African heritage (see Palmié 2013). As the title of his 1963 article indicates, Waterman felt the controversy was not only dead but that it had been won by his side. So why flog this horse again, more than half a century later? Simply put, I believe Waterman's horse is, to borrow Lévi-Strauss's well-known interpretation of totemism, "good to think" (Lévi-Strauss 1963:89).

In his work on the African Diaspora, Waterman argued that contemporary African-American musical performances were living proof- "survivals"-of West African cultural heritage even if the performers did not themselves recognize the legacy they bore. Waterman "flogged the horse," so to speak, primarily by drawing historical conclusions from analyses of the musical present. Although this approach was replete with epistemological and methodological flaws, it nevertheless offers insights regarding the historicity of musical performance and thus helps lay the groundwork for a genealogical approach that foregrounds ethnography as a methodological step in what ethnomusicologist Thomas Solomon calls "postcolonial music history" (2012:225).

Still, the present essay should not be read as a methodological roadmap. And irrespective of what might be gleaned from its title, this essay also offers little commentary on the "horse" itself (that is, the Africanisms controversy), which, if indeed dead by 1963, was shortly thereafter resuscitated and has been repeatedly "mounted" (as it were) ever since (e.g., Lovejoy 1997; Palmié 2013; Parés 2005). Instead, my goal is to reread and critique Waterman's work while also expanding his approach, to address how his understanding of historical objectivity might pertain to contemporary ethnomusicology, particularly as our discipline grows increasingly interested in "historical ethnomusicology" (e.g., McCollum and Hebert 2014). ${ }^{1}$ Finally, although I conclude the essay by offering an abbreviated case study taken from my own research on Catholic patron saint rituals in Bahia, Brazil, ${ }^{2}$ the bulk of this text is a critical analysis-rather than a practical application-of Waterman's work.

\section{Richard Alan Waterman (1914-1971): Some Biographical Notes}

In 1943, Richard Alan Waterman (see Figure 1, below) received a PhD in anthropology from Northwestern University, where he later went on to teach and help establish, in 1944, the Laboratory of Comparative Musicology, of which he also served as director. Over the course of his three-decade career, Waterman published on the musical (and non-musical) aspects of culture in a great number of geographical areas, ranging from North and South America to Africa, Asia, 


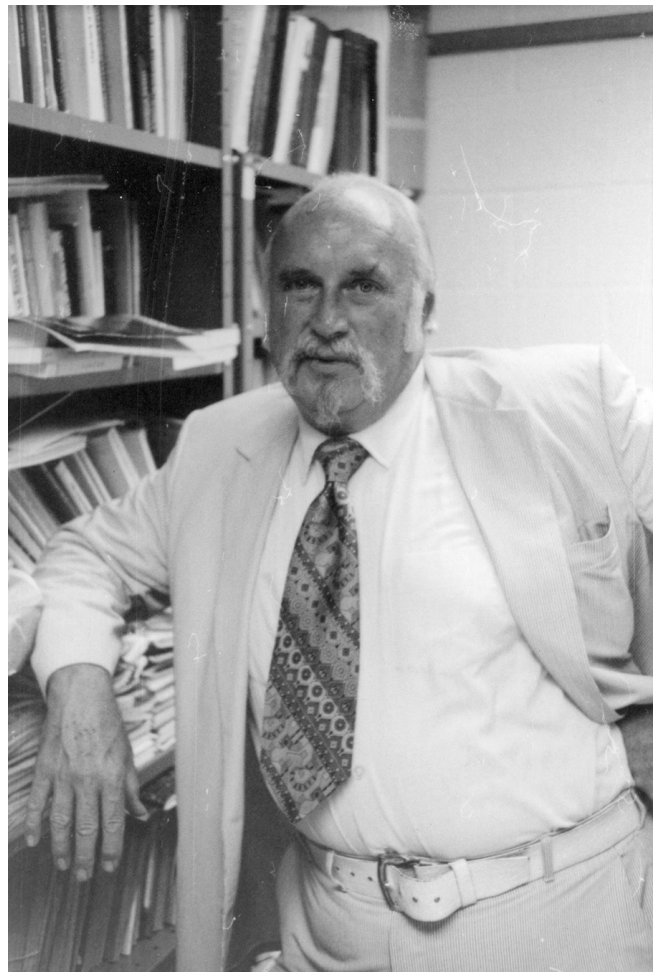

Figure 1: Richard Waterman at the University of South Florida, 1971. Photo, courtesy of Christopher Waterman.

and Australia. ${ }^{3}$ No doubt his most meaningful legacy, however, remains his work on musical "Africanisms," and specifically African rhythm, in New World "Negro music" (R. Waterman 1943, 1948, 1952, 1963).

As was customary for ethnomusicologists of his generation, Waterman did not write in-depth ethnographic accounts about the music he studied. Rather, his most significant publications about New World musics were comparative "laboratory" studies based primarily on data from secondary sources, sound recordings, and his own experience as a musician (R. Waterman 1948, 1952). ${ }^{4}$ This is not to suggest that Waterman conducted no fieldwork in the Americas (see Figure 2, below), but several weeks making field recordings in Puerto Rico (1946) and Cuba (1946 and 1948) coupled with some time spent studying jazz and gospel music in US cities (Merriam and Gillis 1973:85), hardly constituted the kind of extensive fieldwork needed for a deep ethnographic study, even by the less demanding standards of the period..$^{5}$

Waterman certainly pioneered a method of systematically and comprehensively studying Africanisms in American musics, but he was not the first 


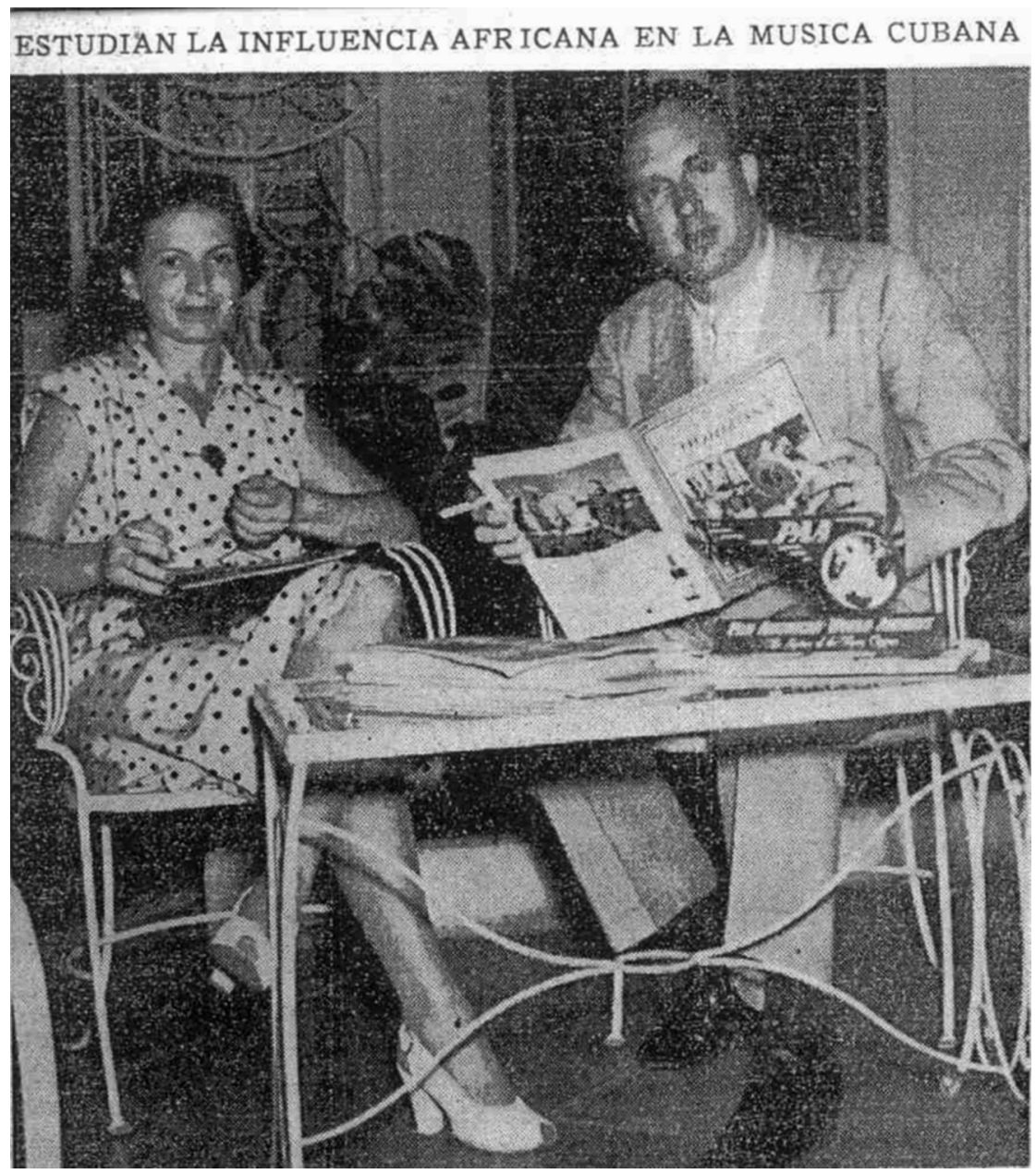

Figure 2: Richard Waterman with Berta Montero in Havana, c. 1948. The Spanishlanguage headline above the photograph reads, "They study the African influence in Cuban music." Photo of unknown newspaper clipping, courtesy of Christopher Waterman.

to take an interest in the subject. An important early study was Erich M. von Hornbostel's (1926) "American Negro Songs." In his article, the Austrian comparative musicologist argued that African and African-American musics were rhythmically, melodically, and harmonically distinct, sharing only a common "way" of singing. Believing the connection to be much more profound, Waterman devoted a large portion of his dissertation's literature review to a painstaking 
deconstruction of each aspect of Hornbostel's argument, while also leveling critiques against other scholars who, Waterman felt, did little more than reproduce Hornbostel's erroneous interpretations. At the same time, however, Waterman was unabashed about his admiration for the work of Polish-born musicologist Mieczyslaw Kolinski. ${ }^{8}$

The influence of Kolinski's work on Richard Waterman cannot be overstated. Not only did Waterman agree with the musicologist's claim that European and African musics were closer than had been assumed by scholars such as Hornbostel, but he also relished in the objectivity of Kolinski's "scientific" approach to the study of West African traits in New World musics. For example, regarding Kolinski's extensive contributions to Melville and Frances Herskovits's (1936) Suriname Folklore, Richard Waterman writes:

The work of M. Kolinski in devising a classificatory system of modes should be of the greatest possible value to a science of comparative musicology. . . While the applicability of Kolinski's method of modal classification to all folk music has not yet been generally accepted, there is no question as to its usefulness when drawing comparisons between European and African music styles. (R. Waterman 1943:67)

It is perhaps unsurprising, then, that Waterman adopted Kolinski's comparative method in his doctoral work on African patterns in Trinidad's "negro music" (R. Waterman 1943).

It should be noted, however, that Richard Waterman paid far more attention to meter, rhythmic phrasing, and percussion instruments than had Kolinski, ${ }^{9}$ and rhythm became an increasingly central interest for the anthropologist over the course of his career (R. Waterman 1948, 1952). Still, what this suggests is that Waterman's preoccupations with systematizing methods of measuring African rhythmic elements in African-American musics may largely have followed from a desire to build upon the musicological approach first initiated by Kolinski. But Kolinski was hardly the only, or even necessarily the primary, influence on Waterman's study of musical Africanisms in the New World. Indeed, Waterman's theoretical framework and interpretive language derived overwhelmingly from the work of his mentor, anthropologist Melville J. Herskovits.

\section{Melville J. Herskovits and Afroamerican Studies}

Remarking on the intellectual overlap between Melville Herskovits and Richard Waterman, ethnomusicologist Christopher Waterman has characterized his father's work as, "in a sense, the musical portion of Herskovits's program" (1991:176). More specifically, Richard Waterman's debt to Herskovits included an intellectual project focused on Africanisms in the Americas, a methodology for studying acculturation, and a relativist concept of culture rooted in the psychophysics-influenced work of Herskovits's own mentor, Franz Boas 
(ibid.:173-174). ${ }^{10}$ Following Boas, Herskovits understood culture as socially learned-rather than biologically inherited-and therefore always open to change. At the same time, however, he believed culture to be intrinsically conservative, and would thus favor reproduction over change. In this Boasian tradition, in other words, culture was paradoxical by nature.

Partly in an effort to contemplate the dynamics of this paradox, Herskovits turned to the acculturation of Africans in the New World. In the project he called "Afroamerican studies" (Herskovits 1946:337), Herskovits sought to explain what was African in African-American culture by evaluating degrees of retention, thus assessing the larger anthropological question of cultural change. In general terms, Herskovits viewed culture as a closed system of "elements" (i.e., religion, language, social organization, etc.), each of which varied in its centrality to the system. Put otherwise, in any given culture certain elements were more important than others. Therefore when two cultures came into contact-in this case European and African-each cultural element, depending on its centrality, would be replaced entirely by the corresponding element of the dominant group's culture, be preserved partially in mixed form, or be wholly retained.

For Herskovits, economics represented an example of total replacement. Since only the European economic system appeared to exist in the New World, Herskovits reasoned that economics was not a "cultural focus" for Africans. ${ }^{11}$ Partial preservation, Herskovits asserted, took the guise of syncretism or reinterpretation. Syncretism was the "tendency to identify" equivalent elements between the cultures while reinterpretation-which took place when cultural equivalences were too weak to sustain syncretisms-was the refashioning of previous cultural elements within the molds of the dominant culture (Herskovits 1946:350-351). ${ }^{12}$ Finally, elements of culture were retained completely when they were "carried below the level of consciousness" (ibid.:352). These subconscious "cultural imponderables," as he called them, included linguistic patterns, musical styles, motor habits, values, and etiquette.

\section{Waterman, the Concept of "Hot," and the Objective Approach}

Richard Waterman embraced Herskovits's framework to identify retentions, syncretizations/reinterpretations, or replacements of African musical style in the New World. Reflecting on his own work, Waterman explains: "My own contributions to the [Africanisms] controversy consisted in pointing out that ... the West African musical style ... changed only through the incorporation of new musical elements that could be reinterpreted to fit it, and further, indicating the kinds of musical norms from West Africa that have persisted in the New World, in somewhat specific terms" (R. Waterman 1963:83). 
These two issues were both important and distinct. The first point essentially returns to a critique of Hornbostel, who had asserted the incompatibility of European and African musical systems (e.g., Hornbostel 1926, 1928). By insisting on the possibility of reinterpreting new elements to fit a West African style, Waterman was arguing that African music could "survive" in syncretic and reinterpreted forms. His second declared contribution-the establishment of "musical norms" whose identification in the New World could serve as proof of an African heritage-has no doubt been the more enduring of the two.

Diverging from his earlier Kolinski-influenced focus on modes, Waterman codified norms pertaining nearly exclusively to aspects of African rhythm; and he justified this focus by noting that " $\mathrm{t}]$ he outstanding feature of African music which sets it most apart from that of Europe is the rhythm" (R. Waterman 1952:211). For Waterman, African rhythm could be identified in five related phenomena: (1) the "metronome sense," an unconscious perception of the beat that was bound to an inherent corporeality; ${ }^{13}(2)$ dominance of percussion and percussive performance techniques; (3) off-beat phrasing of melodic accents; (4) overlapping call-and-response patterns; ${ }^{14}$ and (5) polymeter (R. Waterman 1948, 1952). ${ }^{15}$ Although not without some critique (e.g., Agawu 2003; Maultsby 2005), many of these conceptual categories have become fairly standard in scholarship on African and African-American music (e.g., Chernoff 1981; Danielsen 2006; Gaunt 2006; Kvifte 2007; McLeod 2009; Merriam 1959; Stone 1985; Temperley 2000). Surprisingly, however, while scholars have embraced (or at least acknowledged) these reified traces of Africanity, they have virtually ignored Waterman's more challenging and provocative concept of "hot," of which these traits had initially served only as diagnostic markers.

Waterman's concept of hot, a notion he first theorized in the early $1940 \mathrm{~s},{ }^{16}$ was "take[n] from a linguistic concept of West African tribesman," for "[e]verywhere, Negro music differs from the music of impinging non-Negro groups in being 'hotter"' (1948:24). Unlike the aforementioned traits of African rhythm, the concept of hot was "one of those subliminal constellations of feelings, values, attitudes, and motorbehavior patterns [... ] carried below the level of consciousness, often unrecognized by those who adhere to it" (ibid.). This internal, subconscious impulse - something Waterman called a "cultural intangible" (ibid.:30)—moved agents to feel, perceive, and act in the world in specific ways. ${ }^{17}$

At first glance, to theorize on a concept of hot may appear to betray the "science of comparative musicology" for which Waterman enthusiastically lauded Kolinski. After all, a concept nestled in the recesses of the psyche seems hardly measurable with the kind of objectivity to which Waterman was relentlessly committed. Yet there was in fact no inconsistency at all. The subconscious concept of hot could be objectively studied, Waterman insisted, by way of musical 
transcription: "the dynamic graphs which we know as written music provide us with a tool for the study of the overt correlates of these subconscious factors" (R. Waterman 1948:24). ${ }^{18}$ In other words, since the "hot" concept determined specific "overt correlates" (i.e., musical behaviors), those correlates could be treated objectively (via transcription) as diagnostic elements in the study of "subconscious factors," such as the elusive concept of hot.

Today it surely goes without saying that musical transcription is anything but objective (e.g., Marian-Balasa 2005). Even Waterman himself was attentive to some of the difficulties of transcribing "primitive" and "folk" music (R. Waterman 1943:5-7). Still, he insisted that objective and accurate written representations were possible as long as the music specialist was adequately aware of the concepts that "deviate from those around which the transcription system was originally designed" (ibid.:7). As such, transcriptions offered an objective tool for demonstrating the presence of "hot" musical behaviors-and thus the subliminal hot concept-all over the New World. What is more, since Waterman recognized the hot concept as having arrived with enslaved Africans, he viewed his musicological project as one that provided empirical evidence of a historical African link to the Americas. But for Waterman, this was a broader approach to music research that could go far beyond the Africanisms controversy.

Though Waterman rarely discussed his work in abstract theoretical terms, one exception comes in the form of a panel discussion at the 1958 meeting of the Society for Ethnomusicology in Massachusetts:

We've said some bad things about the counting of intervals, about statistics. I am an anthropologist. I see great value in analytical work such as careful measurement of acoustical phenomena.... History may be traced through analysis. In seeking to find out things about style the informant may be totally unaware of what you want: such ideas are outside the vocabulary and thought of many peoples. It has been said that the "objective approach" isn't really objective, but there are ways of plotting facts which are objective and convenient. (McAllester 1959:104-105)

Though he speaks here specifically about "acoustical phenomena," Waterman's own work suggests that he did not conceive of style as limited to sound, but rather as something that also included movement, language, and performance practices. Thus in his call to trace history through analysis, he may in fact be implying something more holistic than just transcription. The main point I wish to emphasize, however, is that he envisioned his "objective approach" to music as a historical methodology. ${ }^{19}$ Musical performance becomes a historical site and its analysis a mode of archaeology. The implication is that musical ethnography may have much more to say about the empirical past than many scholars recognize. But before this objective approach can be truly useful, it needs to be reexamined more carefully. 


\section{How Not to Flog a Horse: Some Fallacies of the Waterman Approach}

Given its intellectual parentage, Waterman's methodology unsurprisingly suffers from many of the same intellectual shortcomings that haunt Herskovits's work, including essentializing African ethnic groups, compressing time, and denying African history (see Apter 1991; Palmié 2013). Take, for instance, a revealing passage in which Waterman describes the methodological value of sound recordings:

Ethnomusicological study over the past two decades has done much to make available the patterns of West African music, and the phonograph record and magnetic tape have made it possible for us to become aware of its sounds.... [T] he new understanding of African musical characteristics ... gave us some precise indication of stylistic elements in American Negro music to look for if we were actually to find out whether any African contributions remained. (R. Waterman 1963:84-85)

Here Waterman explains that he can establish "patterns" (what Herskovits called a "baseline") of West African musical style by analyzing recordings and then tracking them down in the New World. The feasibility of such a methodology rested on a series of assumptions including, among other things, the homogeneity of a musical style he could call "West African" and its relative stasis from the beginning of the slave trade until (at least) the mid-twentieth century.

Waterman used West African music to establish his musical baseline, presumably because he accepted his mentor's misguided insistence on "the preponderantly West African origin of the Negroes of the New World" (Herskovits 1936:15). ${ }^{20}$ Waterman often employed the broad moniker "African music" as shorthand for music from West Africa (R. Waterman 1948, 1952). However, his consistency of usage suggests that this resulted from rhetorical imprudence rather than a conceptual neutralizing of continental African differences such that West Africa could metonymically represent all of Africa.

But Waterman's treatment of West and Central African music as essentially the same was far from just semantics. As late as 1963, for instance, the anthropologist explained that "[a]lmost all of the African slaves in the Western Hemisphere stemmed from the musically fairly homogeneous strip of territory along the western coast of Africa from Sierra Leone to Angola" (R. Waterman 1963:85). This unsubstantiated generalization conflates the music of Central West and West Africa into a single "West African" style, thus inadvertently ignoring differences between people and regions, histories and values (Agawu 2003:58-62; Kubik 1979:15-22). ${ }^{21}$

While a good case might be made that some broad musical commonalitiesresponsorial singing, time-lines, interrelations of music and dance, etc.-were shared by the various sub-Saharan ethnic groups enslaved in the Americas (see 
Kubik 2010; Stone 1997), to meld the diversity of Central West and West African musics into a single homogenous body compresses centuries and immediately makes irrelevant the complex demographic history of the slave trade. Indeed, the empirically unfounded focus on an imagined homogeneous African homeland from which rhythm had been wholly exported to the Americas ignores the subtleties of historical processes and erases centuries of change and innovation. ${ }^{22}$ Still, these issues are but symptoms of a much deeper and penetrating epistemological flaw: the denial of African history.

As with Herskovitsians generally, Waterman was making a historical case with limited historical data. His geographically narrow sources were, at most, a few decades old. His essay on hot rhythm, for instance, relied on Herskovits's fieldnotes, musicological publications, field recordings, musical analyses, two West African "informants," and his own interest in jazz (R. Waterman 1948:24, n. 2). The viability of making diachronic inferences from these synchronic sources, thus obfuscating the boundary between the past and present, was built on an implicit assumption about the unchanging nature of African music and culture. As such, the methodology implicitly perpetuated the enduring fallacy that non-Western culture is timeless except upon contact with the West. To give any credence to Waterman's historical inferences, then, the ethnographic data must be supplemented with empirical historical data, what Bevir (1994) calls "accepted facts," rigorously gleaned from archival documents, iconography, travelers' accounts, oral history, and so on.

Of course, this misguided essentialism, blatant anachronism, and precarious methodology were not unique to Waterman's approach. Rather, these flaws in some ways characterize much of the anthropological and musicological work of his era. But the approach is still flawed, so why revisit it? Despite the glaring problems I see in Waterman's approach, with some careful rethinking and a methodological overhaul, I believe its theoretical backbone, that music is a site of (subconscious) historical knowledge, may shed some new light on ethnography and ethnomusicology more generally.

\section{The Cultural Intangible: Layered Webs of Histories}

The subconscious "cultural intangible" was the conceptual cornerstone of Waterman's work on Africanisms. Whether analyzing hot rhythm, the metronome sense, or jazz phrasing, Waterman presumed the tenacity of a key intangible, the concept of hot, or what he, in the following passage, calls the "tradition of 'hot' rhythms":

The demonstration that the tradition of 'hot' rhythms, born in Africa, has survived the tremendous social, economic, and religious changes that have fallen to the lot of the carriers of that tradition, is no less important in indicating the almost incredible 
toughness of basic musical culture-patterns than it is in attesting the genuine musical value of the concept. For the 'hot' rhythm of Negro music, now so influential in the music of the New World, has proved its strength by the sheer fact of its survival (R. Waterman 1948:37).

From a twenty-first-century perspective, the autonomy Waterman ascribes to the hot tradition is somewhat disconcerting. Indeed, "hot" is here anthropomorphized into a self-asserting agent whose magical strength seems to determine its continued existence. Humans, in this case, are but "carriers" of an enduring Africanity.

If we turn to a prior passage in the same essay, however, we get a different perspective:

The ability to dance in a 'hot' style was a valuable attribute for a slave, who often gained preferential treatment and prestige in direct ratio to his virtuosity and entertainment-value as a dancer.....The dance is one training-ground for the concept of "hot" which has not suffered from white disapproval. (R. Waterman 1948:30)

Two points are crucial here, for they seem to contradict the previous citation. First, from Waterman's use of the term "training-ground" we can infer that the concept of hot may not actually bounce autonomously from one generation to another, but must instead be practiced and learned by human agents. Second, the notion that dancing in a "hot' style" was a "valuable attribute" because it brought the slave preferential treatment suggests that Waterman may in fact have envisioned slaves as consciously motivated actors and not mere "cultural dupes" (Bohman 1999) beholden to the hot tradition.

This suggests a subtle distinction between the "cultural intangible" (the internalized concept of hot) and its "overt manifestations" (dancing in a hot style), wherein each occupies a different position in the consciousness: the cultural intangible was passively carried below the level of consciousness while its overt manifestations were actively and consciously reproduced. Consequently, the actions that embodied the intangible were motivated by individual meaning-what Sahlins (1981) called "interest"-while those actions inadvertently led to the propagation (i.e., "survival") of the subconscious intangible. In this way, the intangible concept of hot, understood as a vestige of Africa, might most plainly be understood as history, and the decision to dance "in a 'hot' style" as purposeful action in the present, a performance (in the broadest sense).

Reframed in these terms, Waterman's intangible closely resembles Bourdieu's habitus, "a product of history [that] produces individual and collective practices-more history-in accordance with the schemes generated by history" (Bourdieu 1990:54). But unlike the homologous and all-encompassing habitus, cultural intangibles pertained to specific social institutions (such as language, movement, music, etc.) and were therefore multiple and circumstantial. Waterman's "overt manifestations," in this historicized practical sense, might best be 
conceptualized in terms of Connerton's (1989) "habit memory," or what anthropologist Rosalind Shaw theorizes as "practical memories," vehicles of forgotten histories "embedded in habits, social practices, ritual processes, and embodied experiences” (2002:7).

Connerton's and Shaw's neologisms, though subtly distinct, insinuate a simple notion: all performances have historicity. However, this is not the capricious and mutable historicity characteristic of narratives (Bohlman 2008) or social memory (Reily 2001), which are subject to the politics of the present. Rather, I am referring to historicity as "the materiality of the socio-historical process" (Trouillot 1995:29), what Hirsch and Stewart (2005) identify as "historicality." In this sense, to assert that performances have historicity is to assert that they possess real, empirical pasts even if those pasts remain unacknowledged by their enactors. This is possible because " $[w]$ hat happens leaves traces ... that limit the range and significance of any historical narrative" (Trouillot 1995:29). Some traces, as Trouillot poignantly notes, "are quite concrete-buildings, dead bodies, censuses, monuments, diaries, political boundaries" (ibid.). Other traces-movements, perceptions, truths-are less concrete, but are no less real. The present is marked by physical structures as well as social ones. After all, it is our structured (and structuring) structures that inevitably shape not only our social lives but also our individual agency (Turner 1997). History, in other words, is inscribed in the present in myriad ways, "stored" not only in the permanent, but also in the ephemeral.

There is more, however. Since an embodied history cannot exist unless it is performed, the performance must always be relevant to contemporary actors. Thus, for the concept of hot to survive, people have to want to dance, sing, and drum in hot ways. Yet the reasons they choose to dance, sing, or drum may be entirely conceptually divorced from hot. Put otherwise, because the intangible (or history, if you prefer) is subconscious, the overt manifestation (or performance) may be, and usually is, motivated by sets of historical factors that have little or nothing to do with its own historicity. After all, the immanent histories of a performance need not be made explicit for an agent to find the act meaningful to him or her. Cultural signs change over time as they are placed into novel relationships with their referents (Sahlins 1981), but this does not necessarily mean that the original sign, as an object, will lose its historicity. This is not to say that cultural signs do not also change, for they often do. Over time and for any number of purposeful or unexpected reasons, a dance form might be condensed or the notes of a melody altered, but just as the rubble from a collapsed building retains the fractured history of the edifice it once was, whole pasts may remain dormant in a simple corporal gesture or melodic contour. ${ }^{23}$

To reiterate, even if a performer is unaware of the history embodied in a particular act, the history does not simply disappear. To take a concrete analogue, 
the cracks on a clay pot (and the immanent socio-historical processes that put them there) never simply disappear because no one knows (or cares) how they got there. In fact, this was precisely Waterman's point and it helps explain why his "objective approach" made any sense at all. But we should not stop here, as this approach opens the floodgates for a series of enquiries regarding history, music, and performance that push beyond Waterman's original intentions. What Waterman never noted, perhaps due to his inattention to the virtues of ethnography, is that the individual resignification of behaviors under novel circumstances creates new histories that can obscure or silence the old ones without ever erasing them. Histories accrue.

A new history can never substitute a forgotten one, as if taking its place in a relay race. Rather, the new history simply joins the move through time as yet another layer of a diachronically rich performance, thus reframing "past" as, to quote Diana Taylor, a "multilayered sedimentation, a form of virtual density rather than a horizontal sweep" (2006:83). Still, since the performance takes place at a given moment in time, it is best imagined not as the apex of a static historical mound but rather as a node enmeshed in a dense network of thick, multilayered horizontal sweeps, all of which, not unlike a Deleuzian rhizome, extend out along a historical plane as lineages of an ever-expanding family tree, randomly intersecting at other historically dense moments, which then intersect with other moments, and so on. For this reason, performances burst with a multiplicity of histories. And the magnitude of a performance multiplies its histories; a ritual, with a dense web of lineages, is more diachronically dense than, say, a hand gesture. Some histories are discursive, many are non-discursive, and still others lie somewhere in-between.

\section{Hearing Silences: Genealogy and Postcolonial Music History}

Conceptualizing performance as a complex layer of different types of historical knowledge makes it somewhat distinct from the type of historical knowledge communicated through narrative. Trouillot once remarked that "[a]ny historical narrative is a particular bundle of silences" because it amasses silences from the "moment of fact creation" to the creation of the narrative itself (1995:26-27). Yet these silences typically go unnoticed, for the seamlessness of the narrative collapses all of these constituent silence-amassing moments under the deceptive guise of linearity and factuality. Performances, on the other hand, when mined in the diachronically dense way I am suggesting, flash all of their constituent histories at once. Embodied in behaviors and ideas, these histories can never be the whole story. Partial and incomplete, these are never readymade linear narratives. Instead they are the snippets of silenced narratives, the fragmented traces of unofficial histories that have been stifled by official accounts. 
Recognizing that silenced histories can be excavated from performance is a move toward devising a strategy to hearing forgotten voices of the past. It is also seemingly a step closer to a Foucauldian genealogy that seeks "to identify the accidents, the minute deviations-or conversely, the complete reversals-the errors, the false appraisals, and the faulty calculations that gave birth to those things that continue to exist and have value for us" (Foucault 1977:146). Building on Foucault's notion, then, to call an approach to music genealogical would be to suggest not only that it investigates historically contingent processes, but also that it moves methodologically from the present to the past in an effort to foreground the historical "accidents" embodied in contemporary musical performance. ${ }^{24}$

An ethnomusicological approach rooted in this genealogical perspective seems especially pertinent to postcolonial contexts. Indeed, one of the deleterious effects of colonialism has been "the death and burial of [the colonized peoples'] local cultural originality" (Fanon 2008:9), resulting in the perversion of the social memory and collective unconscious of the colonized and dominated. This is why, for instance, Brazilian activist and intellectual Abdias do Nascimento introduced his "Quilombismo" by sternly declaring: "I want to begin this text emphasizing the urgent need of the Brazilian Black people to win back their memory" (1980:141). His implication was that Afro-Brazilians had been stripped of their collective memory, cut off "from the trunk of their African family tree" (ibid.:142). And in fact it seems Waterman was quite cognizant of how these manipulative psychological power dynamics could play out. Of the U.S. context, for instance, he remarked that " $\mathrm{t}]$ he slaves were regarded as humans of inferior quality, and their cultural background was ignored. . . . North American Negroes soon learned to be ashamed of their African heritage" (1948:29). Might Waterman's progressive interpretation have driven his focus on performance over discourse? Or was his approach merely coalesced around an older ethnomusicology interested more in music analysis than ethnography?

Either way, it now appears that performance serves as a convenient object of investigation when seeking out colonized histories precisely because its study can subvert the entrenched colonial "inferiority complex" (Fanon 2008) that causes people to forget, deny, hide, or otherwise ignore their collective pre-colonial pasts. If indeed musical performance can effectively harbor a past that colonialism has rendered discursively inaccessible, it is because no matter how naturalized the hegemony - that is, domination veiled in orthodoxy-it is "never total" (Comaroff and Comaroff 1991:25). In this way, a genealogical ethnomusicology that is sensitive to embodied histories may be ideal for work in postcolonial music history, even in assisting in the recuperation of "the musical experiences of the colonised" (Solomon 2012:225).

Before moving on, I would like to offer an observation on methodology. It seems to me that this genealogical perspective, which contemplates the multiple 
layers of historicity, depends on the interplay between good ethnography and rigorous historical work. After all, the approach requires integrating observed (or experienced) musical practices with both empirical historical data (i.e., "objective" history) and the subjective realities of musical agents. As such, a genealogical question during fieldwork may move the researcher to conduct an oral history or an archival search, while a subsequent archival find may then lead the researcher back to the field again, and so on. This dynamic process, which mixes sources, methods, and epistemological assumptions, allows for the creation of several critical dialectics out of which can be born a thick genealogical musical ethnography: past and present, discourse and performance, the "archive" (documented past) and the "repertoire" (performed past) (Taylor 2003), and "the past as represented [in narrative] and the past that occurred" (Apter and Derby 2010:xxviii, n. 7). Seen in this way, the present becomes a robust site of meaning construction and an intricate web of individual interpretations, personal memories, and collective histories.

\section{Case Study: Genealogies of a Patron Saint Celebration from Bahia, Brazil}

In what follows, I offer a practical example of the type of genealogical approach I am encouraging. Since space here is quite limited, I offer only bits and pieces of a much larger study. ${ }^{25}$ I have conducted over half a decade (2008-2014) of ethnographic and archival research on the reza, a musical patron saint celebration common in the majority African descendent Recôncavo region of Bahia, in northeastern Brazil (see Figure 3, below). The reza (literally, "prayer") is a

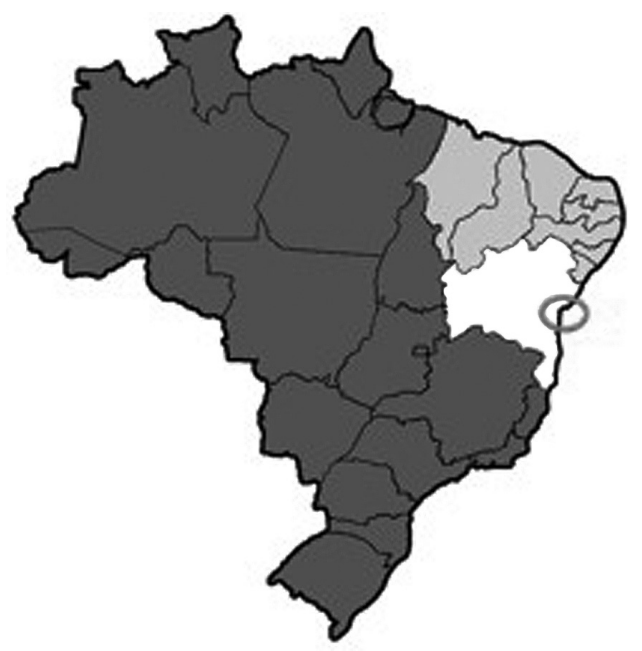

Figure 3: Political map of Brazil. The highlighted state is Bahia, and the circled region is the Recôncavo. (Adaptation of a map created by Ronald Conner.) 
participatory musical event that people hold annually in their homes to honor their personal Catholic patron saints. Rezas usually consist of (1) the a cappella singing of Catholic hymns (novenas); (2) samba, which is sung, clapped, and danced by all present; and (3) group feasting. If by chance the host of the reza also serves as a medium for the quasi-ancestral deity, known as a Caboclo, the samba prompts possession trance dancing (Iyanaga 2010, 2013).

People generally explain rezas as either personal votive offerings or family obligations left to them by a parent or other close relation. In this way, the historical consciousness central to people's understandings of their musical saint devotions is markedly intimate. Thus, histories usually involve the lives of the devotees themselves, their children, their relatives, their community, and local ecclesiastical authorities. Except perhaps for the implicit global history evoked in the view that the reza is part of an international Catholic identity (as are, for instance, baptisms and processions), macrohistory is generally absent from discursive notions of the domestic devotional activity itself. The ritual's other constituent components-liturgies, melodies, texts, dancing, the Caboclo-are never (or rarely) explained or justified in collective socio-historical terms. Instead, the whys for performing these things are rooted in personal and family histories, local social contexts, and general cosmology (Iyanaga 2013, forthcoming). Yet ritual practices embody broader non-discursive histories about social life in Bahia, Brazil, and the Americas more generally.

The domestic devotion to Sts. Cosmas and Damian is one of the most popular in Bahia, and has been for at least a century. In Bahia, and particularly in the Recôncavo, a reza for Sts. Cosmas and Damian begins with a ritual feeding. Seven children, seated on the floor or at a table, feast on caruru (a stew of okra and palm oil), stewed chicken, and a number of other side dishes. Meanwhile, the adults sing any number of songs detailing the attributes of Cosmas and Damian (See Figures 4, 5, 6, and Musical Example 1) as they accompany themselves with

\begin{tabular}{ll}
\hline Portuguese & English \\
\hline São Cosme mandou faze & St. Cosmas requested \\
Duas camisinha azul & Two little blue shirts \\
No dia da festa dele & For the day of his party \\
São Cosme quer caruru & St. Cosmas wants to eat carurú \\
Vadeia Cosme & Play Cosmas \\
Vadeia & Play \\
Tô vadiando & I'm playing \\
Na areia $(2 x)$ & In the sand $(2 \mathrm{x})$ \\
\hline
\end{tabular}

Figure 4: Portuguese-language text of a samba song for Sts. Cosmas and Damian, with English translation. 


\begin{tabular}{ll}
\hline Portuguese & English \\
\hline Cosme, Damião, Doú, Alabá & Cosmas, Damian, Doú, Alabá \\
Sereia no mar mandou me chamar & Mermaid in the sea called for me \\
\hline
\end{tabular}

Figure 5: Portuguese-language text of another samba song for Sts. Cosmas and Damian with English translation.

\begin{tabular}{ll}
\hline Portuguese & English \\
\hline São Cosme é menino & St. Cosmas is a little boy \\
Mas tem a Palavra & But he has the Word \\
Palavra divina & The divine Word \\
Palavra sagrada & The sacred Word \\
\hline
\end{tabular}

Figure 6: Portuguese-language text of another samba song for Sts. Cosmas and Damian with English translation.
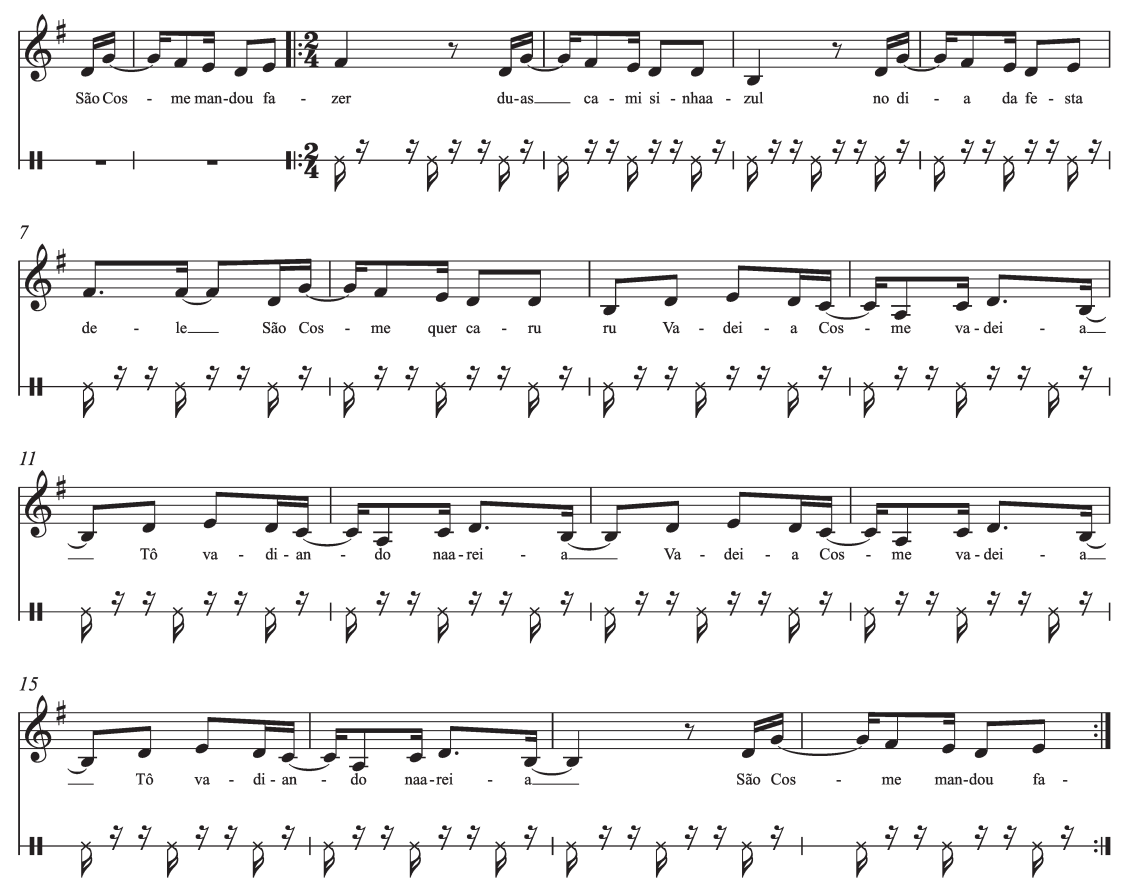

Music Example 1: Transcription of a performance of Figure 3 from September 27, 2011 (Cachoeira, Bahia, Brazil). 
ostinato handclaps (Musical Example 2 and 3). An hour or so later, the adults sing the novena to the twin saints, with the "Bendito," or hagiological hymn, being among the most important songs sung for the saints (Figure 7 and Musical Example 4). The adults then sing additional samba songs, often with drums and chordal instruments, before eating their own plates of caruru.

Hagiological texts, examples of which I provided in Figures 4, 5, 6, and 7, play a heavy role in teaching devotees characteristics of their patron saints. In this case, the texts signal that Sts. Cosmas and Damian are playful, yet wise, children who protect twins and enjoy eating caruru. "Doú" and "Alabá," though referred to in the texts only in passing, are mentioned because they are regarded

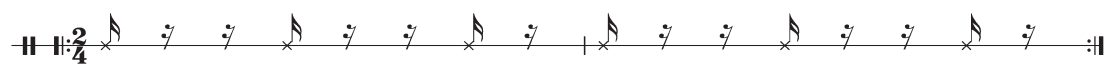

Music Example 2: One of two basic samba rhythm patterns clapped by participants. This is the most popular samba rhythm in Bahia and is the basic rhythm used for the genre known as samba de roda.

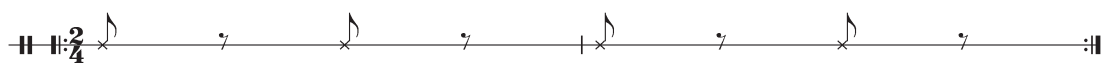

Music Example 3: One of the two basic samba rhythm patterns clapped by participants.

\begin{tabular}{ll}
\hline Portuguese & English \\
\hline Aleluia Aleluia & Halleluiah, Halleluiah \\
Que nasceram dois irmãos & For two brothers have been born \\
Que São João batizou & Who[m] St. John baptized \\
São Cosme, São Damião (2x) & St. Cosmas, St. Damian (2x) \\
Toda mulher que tiver & Every woman who has \\
Dois, dois em uma nação & Twins in a single pregnancy \\
Trate logo de festejar & Be sure to celebrate \\
São Cosme, São Damião (2x) & St. Cosmas, St. Damian (2x) \\
Toda aquela que tiver & All of those woman who have [twins] \\
Que não quiser festejar & Who don't want to celebrate \\
Também há de ter a dita & Also should be warned \\
Que no céu não há de entrar $(2 \mathrm{x})$ & That into Heaven they won’t enter $(2 \mathrm{x})$ \\
\hline
\end{tabular}

Figure 7: Excerpt of text from a popular Bendito (hagiological hymn) for Sts. Cosmas and Damian with English translation. The last two lines of each verse are repeated. 


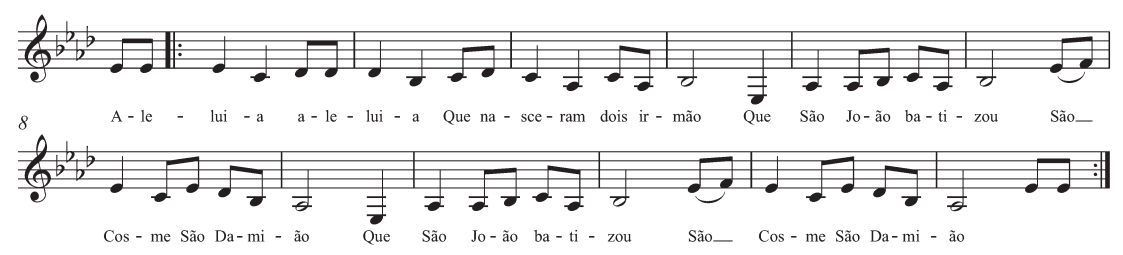

Music Example 4: Transcription of a performance of Figure 7 from August 16, 2009 (Cachoeira, Bahia, Brazil). The melody is shown here with only the first stanza. The text changes for each subsequent stanza but the melodic pattern is repeated with only slight variations.

to be the twins' two younger brothers. Finally, the text in Figure 6 warns mothers of twins that they will suffer divine punishment if they do not celebrate Sts. Cosmas and Damian.

The wide popularity of these sung texts notwithstanding, official written Catholic sources characterize Sts. Cosmas and Damian in a radically different way. Although the Church also identifies Cosmas and Damian as twin brothers, it does not portray them as children. Rather, Cosmas and Damian are said to have been adult doctors who studied medicine in Syria. Tortured and beheaded for preaching the gospel and practicing medicine in Christ's name, the canonized twins subsequently became patron saints of medical professionals (Belém 2005:7; Carvalho 1928:3-18; Farmer 2000:239; Lima 2005:15).

Many researchers have suggested that the discrepancy between the official hagiography and its domestically sung iteration is due to an "unofficial" reordering of the European devotion in Bahia. Accordingly, and in true Herskovitsian fashion, scholars have searched for proof in a seemingly "timeless" African terminology and cosmology (e.g., Bastide 2001; Houlberg 1995; Lima 2005; Omari 1979). It has been noted, for instance, that the reason Doú and Alabá are viewed in Bahia as the twin saints' younger brothers is that for the Yoruba, "Idowu" (a cognate for Bahia's "Doú"26) is the name given to the child who follows the twins and "Alaba" to the child following "Idowu" (Lima 2005; Oruene 1985). Scholars have moreover argued that the Yoruba and Fon provided "the idea that twins bring good luck through proper ritual attention" (Omari 1979:70). The list of one-to-one correlations goes on. But this exclusive reliance on a jumble of loose-albeit convincing-synchronic data as proof of origins sends us meandering down the same ahistorical path so well traveled by Richard Waterman. Let us therefore take a quick look at what the archive suggests.

Leaving aside for now the minutiae, a glance at the available data seems indeed to suggest that West Africans, and probably Yoruba-speakers in particular, played a decisive role in reconfiguring Sts. Cosmas and Damian as caruru-eating 
child saints in Bahia. Socio-religious institutions of the colonial period, for instance, at a time of Central African predominance, show little sign of devotional practices for Cosmas and Damian (Carvalho 1925:56). Instead, the most popular saints were Anthony, Our Lady of the Rosary, and Gonçalo (e.g., Braga 1935; Mott 1996; Reginaldo 2011; Reis 2003). Yet, as West Africans gained social (and demographic) prominence, so too did the twin saints. West African-derived religious practices began gradually to spread (propagated mainly by Gbe-speakers) toward the end of the eighteenth century (Parés 2007), at roughly the same time (from 1780 to 1850) that significant numbers of enslaved Yoruba-speaking peoples were taken to Bahia (Lovejoy 2004).

Therefore by the mid-nineteenth century not only had the enslaved Yorubaspeaking population grown substantially, but they had also achieved a discernible cultural and religious "supremacy" (Parés 2004). Accordingly, by this time, newspapers reported annually on the women who collected alms for residential Sts. Cosmas and Damian parties, festivities that often included drumming and caruru. ${ }^{27}$ By 1897 , the twin saints were counted among the most prevalent saints in Salvador, ${ }^{28}$ and their popularity continued to grow over the course of the early twentieth century (Iyanaga 2010).

This suggests that the devotion to Sts. Cosmas and Damian is a sign of Yoruba cosmological resistance in Bahia. Yet this is not how devotees see it. They explain their patron saint festivities as Catholic "tradition" passed from one generation to the next. These are two entirely different-and arguably contradictory-histories about the same performance. And this is entirely the point. By asking "subjective" and "objective" whys, reality-an entanglement of what is said to have happened and what really happened-can be recast in its complex density and multiple historicities.

Stopping our genealogical investigation here, however, would inadvertently create the kind of linear progression of events - the Europeans arrive, then come the Yoruba, and an Afro-Bahian cult is born! - that Foucault (1977) underscored as the fundamental epistemological distinction between the misguided historian and the meticulous genealogist. Therefore, while the song texts and ritual language may indeed lead us to an unofficial history of the Yoruba in Bahia, the reza itself consists of much more than just language and hagiography. We cannot neglect melodic gestures, rhythms, timbral preferences, choreographic movements, spiritual worlds, etc. And each of these conveys its own specific lineage, creating a denser web of historicity.

To begin with, the entire structure of the event, with a sung novena and a samba, seems to be a trace of the colonial Catholic experience, though surely it extends further into an Iberian past (e.g., Christian 1989). Lay brotherhoods, for example, were central to religious life in Colonial Bahia, and the sodalities' annual patron saint festivities followed roughly the same structure as rezas do 
today: a Catholic liturgy (or paraliturgy) and a collective public celebration, which often included African dances that may well have been antecedent forms of today's samba (Iyanaga forthcoming). Similarly, residential devotional singing, which dates to the colonial period, is perhaps an adaptation of a public Iberian Catholic ritual (Mott 1997:160-161). Domestic singing was in fact so common in the New World that in 1743, authorities at Cuzco (Peru) officially banned the practice of singing the "Salve" in private (Baker 2008:64).

For its part, the samba-as a sound, dance, and socio-religious activity-seems to have developed as part of both the aforementioned brotherhood celebrations and private religious ceremonies called calundus (Iyanaga forthcoming). Calundus, ancestral possession rituals practiced commonly all over Brazil until the late eighteenth century, were, according to historian James Sweet, "scripted in much the same manner as possession rituals in Central Africa" (2003:145). Strikingly, Caboclo possession at rezas resembles the calundu-like Central African-derived style of oracular mediumship-quite distinct, for instance, from Candomblés antecedent West African styles of worship (Parés 2007) - with an added touch of Allan Kardec-inspired Spritism (Garcia 2008; Iyanaga 2013). Finally, the characteristics of the most common samba rhythm (Musical Example, 2, above) have repeatedly been identified as a derivation of a Central African archetype (Döring 2004; Pinto 1991).

These are but a few of the many non-discursive lineages that can be genealogically traced through careful ethnographic research, corroborated, of course, with attention to historical particularities and processes. Additionally, each reza participant also has his or her own (discursive) reasons for celebrating a particular saint as he or she does, turning the singular history of any individual devotion to Sts. Cosmas and Damian into a web of histories, each of which is "stored" in rhymes, melodies, liturgies, movements, foodstuffs, and remembrances. Consequently, to trace a single history is to mine individual decisions, family bloodlines, local social memories, West African cosmologies, Catholic conversion efforts, private domestic singing rituals, public brotherhood festivities, ancestral possession, the colonial experience in Brazil, random occurrences, and the list goes on.

The closer we get with our genealogical eye to the devotion, the more the lineages within it multiply; simplistic linearity reveals itself to be but a fanciful delusion. Under scrutiny, the rhythms, liturgies, spiritual worlds, and ritual movements of the Bahian reza-like "hot" rhythm—all embody multiple histories that go deeper in time and across space than most practitioners or analysts can ever know. Yet, if we explore performances as living archives-and put together the pieces using written documents and other historical materials-we will surely hear untold histories (and her-stories) that may positively transform historical consciousness for performers themselves. 


\section{Concluding Thoughts}

This essay has been a critical review, discussion, and expansion of Richard Waterman's approach to music. For Waterman, history could be traced through musical analysis, what he called the "objective approach," and this is precisely what he did in his studies of New World musics. He believed his contribution to slaying the "horse," his metaphor for the Africanisms controversy, was in demonstrating that African style persisted in African-American musics. To this end, he theorized the "concept of 'hot"' a cultural intangible from Africa that survived below the level of consciousness. Building on this theorization, I elaborated a genealogical approach to music that excavates unofficial histories from musical performance. I concluded by offering an example from my own work in northeastern Brazil.

Using ethnography to voice alternate histories no doubt resonates with the "historical ethnomusicology" first articulated by Kay Shelemay (1980). However, the approach I am advocating here differs in at least one important way: Shelemay's alternate reading of Falasha history relies on corroborating what she calls "ritual formulae" with "commentaries" (that is, oral testimony), while the genealogical approach I am advocating turns decidedly away from discourse. In fact, it embraces possible contradictions between oral testimony and ritual formulae. My approach may consequently be closer to what Daniel Neuman has called "immanent music history", in which "music is the medium . . . and history, its message" (1993:269). Still, as I have tried to show, the message is often anything but singular. When a message is "subliminal," as Waterman put it, it can be embodied in multiple musical sites-a melodic phrase, a choreographic gesture, or an aesthetic proclivity-multiplying thus the messages, as each is layered on top of the other. Any performance, big or small, is capable of telling disparate, fragmented, and even contradictory histories.

Although Waterman developed his approach in the context of the African Diaspora, and my own example derives from the same locus, he did not restrict geographically the concept of subconscious "intangibles." ${ }^{29}$ But whether others can find it valuable in other contexts is left to be determined. On a final note, though my focus in this essay has been Richard Waterman's work, his approach is in many ways just part and parcel of a "school" of ethnomusicology that, having grown out of ethnology and diffusionism, has presumably become outmoded for a feigned scientific objectivity. Yet this approach may be entirely relevant to contemporary concerns. After all, while the dead "horse" Waterman reluctantly flogged fifty-two years ago may be a different beast from the controversies in which we are embroiled today, his "objective approach" may nonetheless be helpful to us in our own battles with the same lingering phantasms of colonialism. 


\section{Acknowledgements}

This essay was written with support from a Fulbright Postdoctoral Research Grant and the Brazilian Coordination for Enhancement of Higher Education Personnel (CAPES). The earliest version of the ideas presented here took the form of a talk given at the University of Illinois at UrbanaChampaign in 2013. Then, nearly a year and a half later, after countless revisions, I presented some of the essay's central ideas at the 59th annual meeting of the Society for Ethnomusicology, held in Pittsburgh, Pennsylvania, in 2014. At both venues I received excellent suggestions, many of which have transformed the final version of this essay for the better. This is no less true for the comments I received from two anonymous reviewers and Ellen Koskoff, the editor of Ethnomusicology. Finally, a special thanks is reserved for Christopher Waterman, who read an early draft of this essay and generously offered me both transformative criticisms and an inside perspective regarding his father's work and intellectual heritage.

\section{Notes}

1. While history has never been totally absent from ethnomusicology (Nettl 1958), synchronic studies focused on the present have tended to dominate the field at least since the mid-twentiethcentury, when fieldwork became the favored methodology for ethnomusicologists. In recent years, however, historical concerns have been growing in ethnomusicological scholarship. One indicative sign, for instance, is the Society for Ethnomusicology's establishment, in 2014, of a Historical Ethnomusicology Section.

2. The ethnographic and archival work on which this essay is based were conducted in Bahia between 2008 and 2014. I gratefully acknowledge funding from the Fulbright Commission, UCLA, and TIAA-CREF.

3. As far as I am aware, Waterman's work on Asia was limited to the compiling of an extensive bibliography on Asian music (e.g., Waterman, Lichtenwanger, Herrmann, Poleman, and Hobbs 1947). This was eventually published in fifteen installments, over the course of five years (19471951), in the journal Notes. On the other hand, Waterman's work in Australia, formally published in the form of an essay collection (Pilling and Waterman 1970), was a one-year fieldwork project that the anthropologist carried out with his wife between March 1952 and March 1953 (Merriam and Gillis 1973:85). Waterman's publications on African-American musics included comparative studies (e.g., R. Waterman 1948, 1952), case studies (e.g., Herskovits and Waterman 1949; R. Waterman 1943, 1951), and book reviews (e.g., R. Waterman 1955, 1957, 1959).

4. A number of authors have commented on Waterman's skill as a jazz bassist (see Bascom 1972; Merriam and Gillis 1973; C. Waterman 1991).

5. See García (2014) for a critical analysis of Waterman's trip with William Bascom to Cuba.

6. According to Waterman, Hornbostel's article on "American Negro Song" was particularly important because "the basic orientation of almost all the more recent publications dealing with the music of the Negroes of the United States is derived from this article" (R. Waterman 1943:14).

7. Though George Herzog recognized Hornbostel's assertion as alluding to "vocal technic" (1936:52), Waterman attributes more ambiguity to Hornbostel's words, suggesting that a "way" of singing might refer to anything from timbre or scale to rhythmic phrasing or motor-behavior (Waterman 1943:24-27).

8. Lydia Parrish (1942) also received significant praise from Waterman for her work with slave songs.

9. Given rhythm's role as a marker of Africa in the Western imaginary since at least the eleventh century (Agawu 2003:55), it is significant that Kolinski turned primarily to modes, harmony, structure, and melodic movement, for evidence of African "retentions." 
10. See George Stocking (1968) on Franz Boas's move from physics to anthropology. See Jackson (1986) for Herskovits's intellectual debt to Boas.

11. For examples, Herskovits pointed to the lack of "African economic patterns" in Suriname, Brazil, and the United States (Herskovits 1946:352).

12. For syncretism, Herskovits is perhaps best known for his theory that African gods in Haiti and Brazil, among other places, had been "syncretized with Catholic saints" (Herskovits 1946:351).

13. As Wilson notes, the metronome sense "is really not a musical characteristic at all but a psychological one which proports [sic] to explain a cultural psycho-physical reaction to music" (1974:6). Still, the theory is little more than an extension of an earlier notion regarding the intrinsic link between dance and percussion (R. Waterman 1948:26).

14. The enumeration of five traits comes from Waterman's oft-cited 1952 publication, for in his 1948 article on "hot" rhythm, Waterman lists only four traits of "hot" rhythm (offbeat phrasing, polyrhythms, percussion, and dance-sound connection). Yet he nonetheless hints at the importance overlapping call-and-response patterns would later possess.

15. It must be noted that in 1948 Waterman favored the term "polyrhythm." The terminology notwithstanding, however, he understood polyrhythm as what we would today call polymeter. Waterman notes, for example, that " $\mathrm{t}$ ] he use of what may be called 'mixed metres' [sic] is the outstanding trait of African percussion rhythm" (1948:25). Later in the same paragraph is a lexical, not semantic, substitution: "As the initial major component of 'hot' rhythm, then, we have percussion polyrhythms."

16. Waterman's "concept of 'hot," published in 1948, was first presented at the 9th annual meeting of the American Musicological Society in 1943.

17. I link the term "cultural intangible" to Waterman because of how consistently he used it, but it probably originated with Herskovits, who already used it occasionally and somewhat interchangeably with "cultural imponderable" during the 1930s.

18. A half-decade earlier, Waterman argued that "the symbolic system used for writing [music]" (1943:4) could "be used to characterize musical styles in strictly objective fashion" (ibid.:1).

19. Although contested, the use of stylistic evidence to determine dates of compositions counts among those tools fairly common to historical musicology (e.g., Brown 1974; Stinson 1989).

20. A number of scholars have called attention to the fundamental role of Central Africans in the New World (e.g., Heywood 2002; Reginaldo 2011; Sweet 2003; Thompson 1983).

21. Surprisingly, Waterman actually painted African harmony in far finer strokes, warning that "the great variety of styles [in Africa] actually present must never be lost sight of" (R. Waterman 1952:208).

22. This includes, beyond local New World adaptations and negotiations, inter-American influences such as the Caribbean music influence on the earliest styles of jazz (Washburne 1997). Or the perhaps less probable, but not impossible, chance that aspects of so-called "African style" resulted by way of larger trans-Atlantic processes (Palmié 2010) or that New World creations were taken "back" to Africa by "returnees" (Matory 1999; Verger 1987).

23. Common examples of intentional melodic alterations are cover versions of pop songs or rearrangements of jazz standards. Less deliberate modifications frequently occur as well, as Charles Seeger (1966) famously demonstrated in his comprehensive analysis of variations of the ballad "Barbara Allen," in non-commercial, orally transmitted songs.

24. Julia Byl's (2014) stunning and innovative exploration of the multiple histories performed in Toba Batak music shares much with the approach I encourage here. Yet it is important to note that our understandings of the term "genealogy" are fundamentally distinct. In a theoretical adaptation of the Toba concept of tarombo, Byl conceives of genealogies as being "always about the present. ... When they are no longer recognized by those they describe, they die" (57). My understanding of genealogy, on the other hand, which largely draws its inspiration from Foucault's work, is really about contingency and historical circumstance. Genealogies, in this sense, exist independent of human consciousness and can never simply be forgotten. 
25. A larger work inspired in the approach I outline here is currently under preparation.

26. Correio Mercantil, August 12, 1836, p. 4. The newspaper mentions a "Dohú," making it thus evident that the name "Idowu" without an " $\mathrm{i}$ " has existed in Bahia since at least the mid-1830s.

27. O Alabama, May 3, 1864, p. 1; O Alabama, September 25, 1869 (série 56), p. 1; O Alabama, September 26, 1871 (série 85), p. 1. Many thanks to Luis Nicolau Parés for these references.

28. A Coisa, n. 7, October 10, 1897, pp. 1-2. An extended excerpt is provided in Iyanaga (2010).

29. Waterman noted the presence of intangibles in a number of other contexts: Spanish retentions in Puerto Rico, Chopi retentions in South Africa, Ainu retentions in Japan, and Polynesian retentions in American Samoa (Merriam and Gillis 1973:82; R. Waterman 1963:86).

\section{References}

Agawu, Kofi. 2003. Representing African Music: Postcolonial Notes, Queries, Positions. New York: Routledge.

Apter, Andrew. 1991. "Herskovits's Heritage: Rethinking Syncretism in the African Diaspora." Diaspora 1(3):235-260.

Apter, Andrew, and Lauren Derby. 2010. “Introduction.” In Activating the Past: History and Memory in the Black Atlantic World, edited by Andrew Apter and Lauren Derby, xiii-xxxiii. Newcastle Upon Tyne: Cambridge Scholars.

Baker, Geoffrey. 2008. Imposing Harmony: Music and Society in Colonial Cuzco. Durham: Duke University Press.

Bascom, William Russell. 1972. "Richard Alan Waterman (1914-1971)." Yearbook of the International Folk Music Council 4:146-151.

Bastide, Roger. 2001. O candomblé da Bahia: Rito nagô. São Paulo: Companhia das Letras.

Belém, Maria. 2005. São Cosme e São Damião: Biografia e novena. São Paulo: Paulinas.

Bevir, Mark. 1994. "Objectivity in History." History and Theory 33(3):328-344.

Bohlman, Philip V. 2008. "Returning to the Ethnomusicological Past." In Shadows in the Field: New Perspectives for Fieldwork in Ethnomusicology, edited by Gregory F. Barz and Timothy J. Cooley, 246-270. 2nd edition. New York: Oxford University Press.

Bohman, James. 1999. "Practical Reason and Cultural Constraint: Agency in Bourdieu's Theory of Practice." In Bourdieu: A Critical Reader, edited by Richard Shusterman, 129-152. Oxford: Blackwell Publishers.

Bourdieu, Pierre. 1990. The Logic of Practice. Stanford: Stanford University Press.

Braga, Alberto Vieira. 1935. O culto de S. Gonçalo na Baía (notas subsidiárias). Barcelos, Portugal: Companhia Editora do Minho.

Brown, A. Peter. 1974. "The Chamber Music with Strings of Carlos d'Ordoñez: A Bibliographic and Stylistic Study." Acta Musicologia 46(2):222-272.

Byl, Julia. 2014. Antiphonal Histories: Resonant Pasts in the Toba Batak Musical Present. Middleton: Wesleyan University Press.

Carvalho, Augusto da Silva. 1928. O culto de S. Cosme e S. Damião em Portugal e no Brasil: História das sociedades médicas portuguesas. Coimbra: Imprensa da Universidade de Coimbra.

Chernoff, John Miller. 1981. African Rhythm and African Sensibility: Aesthetics and Social Action in African Musical Idioms. Phoenix edition. Chicago: University of Chicago Press.

Christian, William A., Jr. 1989. Local Religion in Sixteenth-Century Spain. Princeton: Princeton University Press.

Comaroff, Jean, and John Comaroff. 1991. Of Revelation and Revolution: Christianity, Colonialism, and Consciousness in South Africa. Vol. 1. Chicago: University of Chicago Press.

Connerton, Paul. 1989. How Societies Remember. Cambridge: Cambridge University Press.

Danielsen, Anne. 2006. Presence and Pleasure: The Funk Grooves of James Brown and Parliament. Middletown, CT: Wesleyan University Press. 
Döring, Katharina. 2004. “Samba da Bahia: Tradição pouco conhecida.” ICTUS 5:69-92.

Fanon, Frantz. 2008. Black Skin, White Masks. London: Pluto Press.

Farmer, David Hugh, ed. 2000. “September.” Butler's Lives of the Saints, revised by Sarah Fawcett Thomas. Collegeville, MN: The Liturgical Press.

Foucault, Michel. 1977. "Nietzsche, Genealogy, History." In Language, Counter-Memory, Practice: Selected Essays and Interviews, edited by D. F. Bouchard, 139-164. Ithaca: Cornell University Press.

García, David F. 2014. “Contesting Anthropology’s and Ethnomusicology’s Will to Power in the Field: William R. Bascom's and Richard A. Waterman's Fieldwork in Cuba, 1948.” MUSICultures 4(2):1-33.

Garcia, Sonia Maria Chada. 2008. A música dos Caboclos nos candomblés baianos. Salvador: Fundação Gregório de Mattos, Edufba.

Gaunt, Kyra D. 2006. The Games Black Girls Play: Learning the Ropes from Double-Dutch to HipHop. New York: New York University Press.

Herskovits, Melville Jean. 1936. “The Significance of West Africa for Negro Research.” The Journal of Negro History 21(1):15-30.

— 1946. "Problem, Method and Theory in Afroamerican Studies." Phylon (1940-1956) 7(4):337-354.

Herskovits, Melville Jean, and Frances S. Herskovits. 1936. Suriname Folklore. New York: Columbia University Press.

Herskovits, Melville Jean, and Richard Alan Waterman. 1949. "Música de Culto Afro-bahiana." Revista de Estudios Musicales 1:65-127.

Herzog, George. 1936. Research in Primitive and Folk Music of the United States, a Survey. American Council of Learned Societies Bulletin no. 24. Washington, D.C.: American Council of Learned Societies.

Heywood, Linda M., ed. 2002. Central Africans and Cultural Transformations in the American Diaspora. Cambridge: Cambridge University Press.

Hirsch, Eric, and Charles Stewart. 2005. "Introduction: Ethnographies of Historicity." History and Anthropology 16(3):261-274.

Hornbostel, Eric M. von. 1926. “American Negro Songs.” International Review of Missions 15:748753.

1928. “African Negro Music.” Africa 1(1):30-62.

Houlberg, Marilyn Hammersley. 1995. "Magique Marasa: The Ritual Cosmos of Twins and Other Sacred Children." In Sacred Arts of Haitian Vodou, edited by Donald J. Cosentino, 267-283. Los Angeles: UCLA Fowler Museum of Cultural History.

Iyanaga, Michael. 2010. "Samba de caruru da Bahia: Tradição pouco conhecida." ICTUS 11(2):120150.

. 2013. "New World Songs for Catholic Saints: Domestic Performances of Devotion and History in Bahia, Brazil." PhD dissertation, University of California, Los Angeles.

—. Forthcoming. "Why Saints Love Samba: A Historical Perspective on Black Agency and the Rearticulation of Catholicism in Bahia, Brazil." Black Music Research Journal.

Jackson, Walter. 1986. "Melville Herskovits and the Search for Afro-American Culture." In Malinowski, Rivers, Benedict and Others: Essays on Culture and Personality, edited by George Stocking, Jr., 95-126. Madison: University of Wisconsin Press.

Kubik, Gerhard. 1979. Angolan Traits in Black Music, Games and Dances of Brazil: A Study of African Cultural Extensions Overseas. Lisbon: Junta de Investigações Científicas do Ultramar. . 2010. Theory of African Music. Vol. 2. Chicago: University of Chicago Press.

Kvifte, Tellef. 2007. "Categories and Timing: On the Perception of Meter." Ethnomusicology 51(1):64-84.

Lévi-Strauss, Claude. 1963. Totemism. Boston: Beacon Press.

Lima, Vivaldo da Costa. 2005. Cosme e Damião: O culto aos santos gêmeos no Brasil e na África. Salvador: Corrupio. 
Lovejoy, Paul E. 1997. “The African Diaspora: Revisionist Interpretations of Ethnicity, Culture and Religion under Slavery." Studies in the World History of Slavery, Abolition and Emancipation 2(1):1-24.

- 2004. "The Yoruba Factor in the Trans-Atlantic Slave Trade." In The Yoruba Diaspora in the Atlantic World, edited by Toyin Falola and Matt D. Childs, 40-55. Bloomington: Indiana University Press.

Marian-Balasa, Marin. 2005. "Who Actually Needs Transcription? Notes on the Modern Rise of a Method and the Postmodern Fall of an Ideology." The World of Music 47(2):5-29.

Matory, James Lorand. 1999. "The English Professors of Brazil: On the Diasporic Roots of the Yorùbá Nation.” Comparative Studies in Society and History 41(1):72-103.

Maultsby, Portia K. 2005. "Africanisms in African American Music." In Africanisms in American Culture, edited by Joseph Holloway, 326-355. 2nd edition. Bloomington: Indiana University Press.

McAllester, David, ed. 1959. "Notes and News." Ethnomusicology 3(2):98-105.

McCollum, Jonathan, and David G. Hebert, eds. 2014. Theory and Method in Historical Ethnomusicology. Lanham, MD: Lexington Books.

McLeod, Ken. 2009. "The Construction of Masculinity in African American Music and Sports." American Music 27(2):204-226.

Merriam, Alan P. 1959. “Characteristics of African Music." Journal of the International Folk Music Council 11:13-19.

Merriam, Alan P., and Frank J. Gillis. 1973. “Richard Alan Waterman, 1914-1971." Ethnomusicology 17(1):72-94.

Mott, Luiz R. B. 1996. “Santo Antônio, o divino Capitão-do-Mato." In Liberdade por um fio: História dos quilombos no Brasil, edited by João José Reis and Flávio dos Santos Gomes, 110-138. São Paulo: Companhia das Letras.

_ 1997. “Cotidiano e vivência religiosa: entre a capela e o calundu.” In História da vida privada no Brasil: Cotidiano e vida privada na América portuguesa, edited by Laura de Mello e Souza, 155-220. São Paulo: Companhia das Letras.

Nascimento, Abdias do. 1980. "Quilombismo: An Afro-Brazilian Political Alternative." Journal of Black Studies 11(2):141-78.

Nettl, Bruno. 1958. "Historical Aspects of Ethnomusicology." American Anthropologist 60(3):518-32.

Neuman, Daniel M. 1993. "Epilogue: Paradigms and Stories.” In Ethnomusicology and Modern Music History, edited by Stephen Blum, Philip V. Bohlman, and Daniel M. Neuman, 268-77. Urbana: University of Illinois Press.

Omari, Mikelle. 1979. “Ėre Ibéjì Ritual and Imagery: West African Yorùbá Retentions in Brazil.” Minority Voices 3(2):59-71.

Oruene, Taiwo. 1985. "Magical Powers of Twins in the Socio-Religious Beliefs of the Yoruba." Folklore 96(2):208-16.

Palmié, Stephan. 2010. “Ekpe/Abakuá in Middle Passage: Time, Space and Units of Analysis in African American Historical Anthropology." In Activating the Past: History and Memory in the Black Atlantic World, edited by Andrew Apter and Lauren Derby, 1-44. Newcastle Upon Tyne: Cambridge Scholars.

- 2013. The Cooking of History: How Not to Study Afro-Cuban Religion. Chicago: University of Chicago Press.

Parés, Luis Nicolau. 2004. “The 'Nagôization’ Process in Bahian Candomblé.” In The Yoruba Diaspora in the Atlantic World, edited by Toyin Falola and Matt D. Childs, 185-208. Bloomington: Indiana University Press.

—. 2005. “O processo de crioulização no Recôncavo Baiano (1750-1800).” Afro-Ásia 33:87-132. . 2007. A formação do candomblé: História e ritual da nação jeje na Bahia. 2nd Edition. Campinas, São Paulo: Editora da UNICAMP.

Parrish, Lydia. 1942. Slave Songs of the Georgia Sea Islands. New York: Creative Age Press.

Pilling, Arnold R., and Richard A. Waterman, eds. 1970. Diprotodon to Detribalization: Studies of Change among Australian Aborigines. East Lansing: Michigan State University Press. 
Pinto, Tiago de Oliveira. 1991. Capoeira, Samba, Candomblé. Berlin: Staatliche Museen Preussischer Kulturbesitz.

Reginaldo, Lucilene. 2011. Os Rosários dos Angolas: Irmandades de africanos e crioulos na Bahia Setecentista. São Paulo: Alameda.

Reily, Suzel Ana. 2001. “To Remember Captivity: The 'Congados' of Southern Minas Gerais.” Latin American Music Review 22(1):4-30.

Reis, João José. 2003. Death is a Festival: Funeral Rites and Rebellion in Nineteenth-Century Brazil. Chapel Hill: University of North Carolina Press.

Sahlins, Marshall. 1981. Historical Metaphors and Mythical Realities: Structure in the Early History of the Sandwich Islands Kingdom. Ann Arbor: University of Michigan Press.

Seeger, Charles. 1966. "Versions and Variants of the Tunes of 'Barbara Allen", Selected Reports in Ethnomusicology 1(1):120-167. Los Angeles: Institute of Ethnomusicology, UCLA.

Shaw, Rosalind. 2002. Memories of the Slave Trade: Ritual and Historical Imagination in Sierra Leon. Chicago: University of Chicago Press.

Shelemay, Kay Kaufman. 1980. “'Historical Ethnomusicology’: Reconstructing Falasha Liturgical History." Ethnomusicology 24(2):223-258.

Solomon, Thomas. 2012. "Where is the Postcolonial in Ethnomusicology?" In Ethnomusicology in East Africa: Perspectives from Uganda and Beyond, edited by Sylvia Nannyonga-Tamusuza and Thomas Solomon, 216-251. Kampala, Uganda: Fountain.

Stinson, Russell. 1989. “Toward a Chronology of Bach's Instrumental Music: Observations on Three Keyboard Works." The Journal of Musicology 7(4):440-470.

Stocking, George. 1968. "From Physics to Ethnology." In Race, Culture and Evolution: Essays in the History of Anthropology, 133-160. Chicago: University of Chicago Press.

Stone, Ruth M. 1985. "In Search of Time in African Music." Music Theory Spectrum 7:139-148.

_ 1997. "African Music in a Constellation of Arts." In Garland Encyclopedia of World Music, Vol 1: Africa, edited by Ruth M. Stone, 7-12. New York: Routledge.

Sweet, James H. 2003. Recreating Africa: Culture, Kinship, and Religion in the African Portuguese World, 1441-1770. Chapel Hill: University of North Carolina Press.

Taylor, Diana. 2003. The Archive and the Repertoire: Performing Cultural Memory in the Americas. Durham: Duke University Press. . 2006. "Performance and/as History". The Drama Review 50(1):67-86.

Temperley, David. 2000. "Meter and Grouping in African Music: A View from Music Theory." Ethnomusicology 44(1):65-96.

Thompson, Robert Farris. 1983. Flash of the Spirit: African and Afro-American Art and Philosophy. New York: Random House.

Trouillot, Michel-Rolph. 1995. Silencing the Past: Power and the Production of History. Boston: Beacon Press.

Turner, James West. 1997. "Continuity and Constraint: Reconstructing the Concept of Tradition from a Pacific Perspective." The Contemporary Pacific 9(2):345-381.

Verger, Pierre. 1987. Fluxo e refluxo do tráfico de escravos entre o golfo do Benin e a Bahia de Todos os Santos: Dos séculos XVII a XIX. 3rd edition. São Paulo: Corrupio.

Washburne, Christopher. 1997. "The Clave of Jazz: A Caribbean Contribution to the Rhythmic Foundation of an African-American Music.” Black Music Research Journal 17(1):59-80.

Waterman, Christopher Alan. 1991. "The Uneven Development of Africanist Ethnomusicology: Three Issues and a Critique." In Comparative Musicology and Anthropology of Music: Essays on the History of Ethnomusicology, edited by Bruno Nettl and Philip V. Bohlman, 169-186. Chicago: University of Chicago Press.

Waterman, Richard Alan. 1943. "African Patterns in Trinidad Negro Music." PhD dissertation, Northwestern University.

__ 1948. "Hot' Rhythm in Negro Music." Journal of the American Musicological Society $1(1): 24-37$ 
. 1951. "Gospel Hymns of a Negro Church in Chicago." Journal of the International Folk Music Council 3:87-93.

- 1952. "African Influence on the Music of the Americas." In Acculturation in the Americas: Proceedings and Selected Papers of the XXIXth International Congress of Americanists, edited by Sol Tax, 207-218. Chicago: University of Chicago Press.

. 1955. Review of Miles Mark Fisher, Negro Slave Songs in the United States (Ithaca, NY: Cornell University Press). In The Journal of American Folklore 68(269):370-371.

. 1957. Review of Marshall W. Stearns, The Story of Jazz (New York: Oxford University Press). In Notes 14(4):566-567.

1959. Review of Rudi Blesh, Shining Trumpet: A History of Jazz (New York: Alfred A. Knopf). In Notes 16(2):254-255.

. 1963. "On Flogging a Dead Horse: Lessons Learned from the Africanisms Controversy." Ethnomusicology 7(2):83-87.

Waterman, Richard Alan, William Lichtenwanger, Virginia Hitchcock Herrmann, Horace I. Poleman, and Cecil Hobbs. 1947. "Bibliography of Asiatic Musics." Notes 5(1):21-35.

Wilson, Olly. 1974. The Significance of the Relationship between Afro-American Music and West African Music." The Black Perspective in Music 2(1):3-22. 